Semina $\square \quad \mathrm{Nr} 13$

Scientiarum 2014

s. $190-195$

DOI: http://dx.doi.org/10.15633/ss.693

\title{
Czy wszechświat ma początek?
}

Michał Heller, Tadeusz Pabian, Stworzenie i poczatek wszechświata: teologia, filozofia, kosmologia, Copernicus Center Press, Kraków 2013, ss. 177

Książka pt. Stworzenie i początek wszechświata porusza niezwykle ważny dla każdej osoby, a w szczególności wierzącej, problem wypływający z konfrontacji wiary i wiedzy naukowej. Watpliwości wynikajace z tego konfliktu starają się rozwikłać ks. prof. Michał Heller, kosmolog, filozof i teolog, laureat Nagrody Tempeltona oraz ks. dr hab. Tadeusz Pabian, filozof z Wydziału Teologicznego w Tarnowie Uniwersytetu Papieskiego Jana Pawła II w Krakowie. Autorzy konfrontuja ze sobą teologiczne prawdy zawarte w biblijnych opisach stworzenia oraz najbardziej poważane obecnie teorie naukowe dotyczace kosmologicznych i ewolucyjnych aspektów stworzenia.

Publikacja podzielona została na sześć rozdziałów, które ujęte są w dwie części: teologiczną i naukowa. W pierwszym rozdziale przedstawione zostały podstawowe informacje dotyczące biblijnego opisu stworzenia oraz metody jego interpretacji. Uwzględniony przy tym został historyczno-kulturowy kontekst powstania opisu oraz konieczne dla jego zrozumienia literackie, egzegetyczne oraz teologiczne aspekty badanego tekstu. W kolejnych dwóch rozdziałach autorzy zaprezentowali rozwój teologiczno-filozoficznej interpretacji biblijnego opisu stworzenia świata. W rozdziale drugim określone zostały różnice między starotestamentowym spojrzeniem na początek wszechświata a ujęciem tego problemu przez filozofię grecka. Podkreślony tu został wpływ, jaki rozważania starożytnych odcisnęły na światopoglądzie pierwszych myślicieli chrześcijańskich, a co za tym idzie, także na ich rozumie- 
niu biblijnego opisu stworzenia. Wpływ ten wyraźnie ujawnia się również w tekście Nowego Testamentu. Co więcej, Autorzy uwypuklili szczególne znaczenie badań Orygenesa i św. Augustyna na narodziny i rozwój teologicznej refleksji nad stworzeniem. Wypracowane przez ojców Kościoła koncepcje zaczęto jednak podważać na przełomie XII i XIII wieku wraz ze starciem „dwóch tradycji filozoficznych - platońskiej i arystotelesowskiej” (s. 68). Ponowne odkrycie Arystotelesa doprowadziło do zmiany średniowiecznego obrazu świata i wiązało się zarazem z koniecznością aktualizacji koncepcji początku wszechrzeczy. Tym właśnie zagadnieniom poświęcony został rozdział trzeci, który przedstawia stworzona przez św. Tomasza z Akwinu ideę wszechświata istniejącego odwiecznie, stanowiąca rozwiązanie powyższych zagadnień. Na jego teorii kończą się rozważania Autorów dotyczące jedynie warstwy teologicznej przedmiotowego problemu.

Rozdziały czwarty i piąty stanowią natomiast zestawienie $\mathrm{z}$ jednej strony teologicznego ujęcia stworzenia oraz naukowego obrazu tego procesu z drugiej. Pierwszy z nich prezentuje tę problematykę na płaszczyźnie kosmologicznej. Co ważne, Filozofowie nie ograniczyli się w tym miejscu, jedynie do zagadnień związanych z kosmologia relatywistyczną i do wypływającej z niej teorii Wielkiego Wybuchu, ale opisali, także mniej popularne w środowisku naukowym modele „kwantowej kreacji”. Zasygnalizowali także istnienie niezbadanych jak dotąd obszarów współczesnej fizyki, dotyczących choćby kwantowej teorii grawitacji. Opracowanie i eksperymentalne potwierdzenie takiej teorii przynieść może „całkowicie nowe rozstrzygnięcia problemu początku świata, których obecnie nikt się nie spodziewa” (s. 101). Rozdział piąty porusza natomiast kluczowe zagadnienia teorii ewolucji, oczywiście w odniesieniu do problematyki stworzenia. Tytułem wprowadzenia przedstawiono w tym miejscu przekrojowy rozwój tej koncepcji, rozpoczynajac od pewnych intuicji starożytnych z nią związanych, a kończąc na współczesnym rozumieniu ewolucji już nie tylko w aspekcie czysto biologicznym, lecz i kosmologicznym. Autorzy, w celu kompleksowego przedstawienia tej problematyki, rozważyli także główne argumenty fundamentalizmu antyewolucyjnego oraz 
stosunku zachodzącego pomiędzy pojęciem przypadku i „stwórczego zamysłu” Boga. Rozdział szósty jest natomiast podsumowaniem przedstawionej powyżej problematyki i próbą odpowiedzi na pytanie, jaka jest rola nauki we wszechświecie stworzonym przez Boga i jaka relacja zachodzi między nauką a dogmatami wiary. Publikacja zwieńczona została, skierowanym do katechetów, dodatkiem: „Jak uczyć o stworzeniu świata”. Zawarte w nim praktyczne porady i uwagi ułatwić maja przekazanie niezbędnych informacji oraz wskazać najważniejsze problemy związane z procesem nauczania powyższych skomplikowanych zagadnień na lekcjach religii.

Zmierzenie się z zagadnieniami dotyczącymi stworzenia świata wymaga interdyscyplinarnej wiedzy, kreatywności przy stawianiu tez oraz powściagliwości przy wyprowadzaniu wniosków. Wydaje się, że Autorzy temu trudnemu zadaniu podołali. Wyróżnione już na wstępie publikacji przeciwstawienie aktu „zapoczątkowania istnienia w czasie” "odwiecznemu dawaniu istnienia” należy uznać za kluczowe dla zrozumienia poruszonej tematyki. Jak zauważają Twórcy, błędy wynikające z nieodróżniania tych pojęć należą do codzienności w dyskusji na temat stworzenia. Niestety nie unikają ich nawet przedstawiciele nauki, podejmujący rozważania tej kwestii. Uwidacznia się to choćby w pracach współczesnych fizyków roszczących sobie prawo do wypowiadania się o kluczowych zagadnieniach filozoficznych czy teologicznych, jednak opierających się wyłącznie na wiedzy z zakresu własnej dyscypliny. Taka, dość lekceważąca dla osiagnięć innych nauk, postawa prowadzi do opracowywania często śmiałych i chwytliwych, jednak w większości niepoprawnych koncepcji. Przedstawione wątpliwości ujawniają się na przykład w wybranych modelach kwantowej kreacji, których twórcy, zakładając możliwość stworzenia wszechświata ex nihilo, staraja się wykluczyć jakakolwiek rolę Boga w tym procesie, a tym samym zaprzeczyć konieczności Jego istnienia. Wydaje się, że właśnie takie jest przesłanie modelu Hartle'a-Hawkinga, który prezentuje pogląd o możliwość zaistnienia wszechświata, wykluczając zarazem wszelkie warunki początkowe lub brzegowe. Autorzy słusznie zwracają jednak uwagę, że twórcy powyższego modelu zdają się „nie dostrzegać różnicy między naukowym (np. kosmologicznym lub 
kwantowym) i teologicznym rozumieniem «stworzenia»" (s. 113). Zanegowanie początku wszechświata nie musi bowiem prowadzić do negacji istnienia samego Stwórcy. Dopiero wiedząc, że akt stworzenia to niekoniecznie zapoczątkowanie istnienia w czasie, ale jego ontyczna zależność od Boga, można zrozumieć nieadekwatność przedstawionej przez Hawkinga argumentacji. Odrzucenie początku nie podważa w jakikolwiek sposób tej zależności i nie może zostać przyjęte jako dowód nieistnienia Stwórcy.

$\mathrm{Z}$ drugiej jednak strony powyższy zarzut (rozprawiania o specjalistycznych zagadnieniach przez pryzmat jedynie własnej dziedziny) skierować można także przeciwko niektórym filozofom i teologom, którzy przedmiotem swoich wypowiedzi czynią kwestie ściśle fizyczne. Odzwierciedla to choćby stanowisko papieża Piusa XII, który „potraktował teorię Wielkiego Wybuchu jako wzmocnienie argumentacji na rzecz stworzenia świata przez Boga" (s. 97). Utożsamienie początkowej osobliwości z aktem stworzenia dowodzić miało, zgodnie z jego tezami, konieczności Jego istnienia. Nie można jednak przyjąć takiego toku rozumowania. Jak już zostało wcześniej wspomniane, kwestia zapoczątkowania wszechświata w czasie nie może stanowić punktu wyjścia dla dowodu istnienia lub nieistnienia Stwórcy. Wzajemne odróżnienie początku i stworzenia zmusza do przyjęcia tezy, że „zagadnienia dotyczące początkowej osobliwości są całkowicie neutralne wobec teologicznie pojmowanego problemu stworzenia" (s. 102). Nie jest to jednak jedyne zastrzeżenie, jakie należy postawić zwolennikom utożsamiania początkowej osobliwości z aktem stworzenia. Zarzut nawet bardziej poważny stanowi błędne podejście metodologiczne. Zjawiska fizyczne winny być wyjaśniane za pomoca metod charakterystycznych dla tej nauki, a nie poprzez przyjmowanie wpływu czynników ponadnaturalnych wszędzie tam, gdzie naukowe dociekania natrafiaja na trudności. Takie postępowanie może w efekcie prowadzić nawet do podważenia autorytetu Kościoła. Jeżeli bowiem udałoby się potwierdzić koncepcję odwieczności wszechświata, dyskredytując przy tym stanowisko utożsamiające stworzenie $\mathrm{z}$ początkiem, twierdzenia Piusa XII stałaby się faktycznie przeciwdowodem istnienia Boga. 
Pozostając na płaszczyźnie rozważań relacji wiara-nauka Autorzy uznali za zasadne przedstawić zasady kreacjonizmu naukowego, jednego $\mathrm{z}$ najbardziej skrajnych stanowisk $\mathrm{w}$ tej sprawie. Doktryna ta, odrzucająca naturalizm metodologiczny i zakładająca zarazem dosłowne rozumienie biblijnego opisu stworzenia, za cel postawiła sobie podważenie teorii biologicznej ewolucji. Zwolennicy tej ideologii, uznając, że „ani teoria ewolucji, ani żadna inna teoria naukowa nie sa w stanie $\mathrm{w}$ pełni wyjaśnić całej złożoności organizmów żywych i ich doskonałego przystosowania do środowiska" (s. 131) wykluczają opcję powstania życia w sposób przypadkowy. Wynika to jednak z dość arbitralnie przyjętego założenia, iż stworzenie życia przez Boga wyklucza „ślepy przypadek”. Tymczasem, Heller i Pabian rozwiąuja ta pozorną sprzeczność, pokazując, że przypadek może być sposobem działania Stwórcy. Przyjmując bowiem rozumienie przypadku jako zdarzenia mało prawdopodobnego, na które wpływ ma wiele czynników, okazuje się, że pojęcie to nie musi kolidować z zamysłem Boga. Jeżeli dla człowieka możliwe jest określenie przesłanek zaistnienia przypadku, to tym bardziej nie stanowi to problemu dla Boga: „Przypadek nie jest czymś, co wymyka się Bogu spod kontroli, ale jest częścią Jego stwórczego zamysłu" (s. 136). Przypadek, który ze względu na mnogość przyczyn konstytuujących go wydaje się czymś nieprzewidywalnym dla ludzi, z boskiego punktu widzenia jest jedynie logicznym następstwem tych przyczyn. Ewidentnie pokazuje to niezasadność postulatów stawianych przez kreacjonistów naukowych. Wydaje mi się, że dla stanowisk odrzucających potrzebę konfrontowania prawd religijnych i wiedzy naukowej, najlepszym komentarzem są słowa Klemensa Aleksandryjskiego: „Wiara poparta wiedzą ma większa wartość niż sama wiara”.

Reasumując, dogłębne zbadanie problematyki stworzenia musi wypływać ze starcia aktualnego stanu wiedzy z zakresu teologii, filozofii i kosmologii (oraz innych nauk), a nie opierać się na tylko jednym z tych źródeł. Budowanie koncepcji stworzenia w oparciu jedynie o jedną z tych gałęzi nauki prowadzi w oczywisty sposób do zubożenia postrzegania i opisywania złożoności tego zjawiska. 
Lektura tej publikacji pozwala, w mojej ocenie, nawet osobie nieposiadajacej gruntownej podbudowy naukowej i teologicznej na rozważenie i ocenę słuszności poszczególnych argumentów oraz ocenę zasadności koncepcji, która wskazuje celowość interdyscyplinarnego spojrzenia na ten problem. Jak we wstępie stwierdzają sami Autorzy, publikacja skierowana jest głównie do katechetów. Poza ugruntowaniem wiedzy, książka ma wskazać także metody nauczania o stworzeniu, czemu w końcowej części poświęcony został dodatek. Sądzę jednak, że jest to pozycja adresowana do o wiele szerszego kręgu odbiorców. Powinna zapoznać się z nią każda osoba zmagająca się z kwestią pozornej sprzeczności między naukowym i teologicznym obrazem stworzenia i mająca trudność w scaleniu ich w jedną koherentną całość. Jest ona z pewnościa godna polecenia wszystkim poszukującym odpowiedzi na pytania: kim jesteśmy, dokąd zmierzamy, a w szczególności, skąd przychodzimy.

Piotr Karp 